\title{
Tarım İşletmelerinde Girişimciliğin Belirleyicileri Üzerine Bir Çalışma; Konya İli Ereğli İlçesi Örneği
}

Kemalettin AĞIZAN (D), Zeki BAYRAMOĞLU

Selçuk Üniversitesi Ziraat Fakültesi Tarım Ekonomisi Bölümü, Konya

${ }^{1}$ https://orcid.org/0000-0002-2340-2614, ${ }^{2}$ https://orcid.org/0000-0003-3258-3848

$\triangle$ : agizankemalettin@gmail.com

\section{ÖZET}

Bu çalışmanın amacı tarım işletmecilerinin girişimci olma kararlarını etkileyen faktörlerin belirlenmesidir. Bu amaçla, Konya ili Ereğli ilçesinde tabakalı tesadüfi örnekleme yöntemine göre belirlenen 98 tarım işletmecisiyle anket yapılarak girişimciliği etkileyen faktörler doğrusal regresyon ile analiz edilmiştir. Çalışmada bağımlı değişken olarak girişimcilik katsayıları modele alınmış, bağımsız değişkenler olarak ise arazi miktarı, aktif sermaye, gayrisafi üretim değeri, erkek işgücü birimi (EIB), üretici yaşı, sigorta yaptırma, net kar ve eğitim değişkenleri modele dahil edilmiştir. Modelin açılklama gücü $R^{2}$ \%77.50 olarak belirlenmiştir. Modelde yer alan tüm değişkenler t testi sonuçlarına göre istatistiki olarak anlamlı belirlenmiştir. $\mathrm{Bu}$ sonuçlara göre; dekara düşen aktif sermaye miktarı ve yaş değişkenlerinin işaretleri negatif, arazi miktarı, gayrisafi üretim değeri, EIB, sigorta yaptırma, net kar ve eğitim parametreleri ise teoriye uygun olarak işaretleri pozitif belirlenmiştir. Sonuç olarak, eğitim faaliyetlerinin girişimcilik düzeyini artırdığını ve genç yaştaki üreticilerin daha fazla girişimcilik özelliklerine sahip olduğunu ortaya çıkmıştır. Bu nedenle genç çiftçilere eğitim faaliyetlerinin verilmesi, Küçük Ölçekli Tarım İşletmeleri (KOTI) ve teşvikler gibi projelerin desteklenmesi önerilmektedir.

Determination of Factors Affecting Entrepreneurship in Agriculture: Konya Province Ereğli District Survey

\section{ABSTRACT}

The aim of the study was to determine the factors affecting the decision of the entrepreneurship of the agricultural enterprises. For this purpose, a survey was conducted with 98 agricultural enterprises determined according to stratified random sampling method in the Ereğli district of Konya province and the factors affecting entrepreneurship were analyzed by multiple linear regression. In the study, entrepreneurial coefficients were taken as model dependent variables, and the amount of land, active capital, gross production value, MLU, producer age, agricultural insurance, net profit and formal education variables were included as independent variables. The description power of the model $\left(\mathrm{R}^{2}\right)$ was determined as $77.50 \%$. All variables in the model were statistically significant according to t test. Based on the results obtained; The amount of active capital and age variables falling negative, land quantity, gross production value, EIB, insurance, net profit and education parameters were determined as positive according to the theory. As a result, it has been revealed that educational activities increase the level of entrepreneurship and young entrepreneurs have more entrepreneurial characteristics. Therefore, it is recommended to support young farmers such as training activities, small scale agricultural enterprises (SAME) and incentives.

\author{
Araştırma Makalesi
}

$\begin{array}{ll}\text { Makale Tarihçesi } \\ \text { Geliş Tarihi } & : 02.11 .2018 \\ \text { Kabul Tarihi } & : 17.12 .2018\end{array}$

Anahtar Kelimeler

Ereğli

Tarım İşletmeleri

Girişimcilik

Regresyon Analizi

To Cite : Ăğıan K, Bayramoğlu Z 2019. Tarım İşletmelerinde Girişimciliğin Belirleyicileri Üzerine Bir Çalışma; Konya İli Ereğli İlçesi Örneği. KSÜ Tarım ve Doğa Derg 22(2): 294-305. DOI: 10.18016/ksudobil.478031 


\section{GİRIŞ}

Tarihsel olarak çoğu yerleşim yeri deltalar halinde inşa edilmiş olup, bu deltaların en verimli topraklara ve yüksek biyoçeşitliliğe sahip olduğu bilinmektedir. $\mathrm{Bu}$ nedenle bu deltalar stratejik bir öneme sahip olup, tarımsal faaliyetlerin verimli ve etkin olmasında önemli bir paya sahiptiler. Fakat dünya giderek hızla şehirleşmekte olup, bugün dünya nüfusunun yarısından fazlası bu deltaların üzerinde şehirleşmekte ve yaşamaktadır. Bu durum 2050 yıllara geldiğinde \%70 oranında ve 6.5 milyar nüfusun şehirde yaşayacağı öngörülmektedir (Altvorst ve ark., 2011). Bu nedenle bu bölgelerde tarım toprakları için rekabet artmaktadır. Çünkü kentsel nüfus her ne kadar bu deltaların üzerinde yaşasa bile, ihtiyaç duyulan gıdanın temelinde yer alan tarım sektörü bu deltalar üzerinde gerçekleştirilmesi gerekmektedir.

Artan kentleşme ile birlikte tarım ürünlerinde yeni talepler oluşmaktadır. Oluşan bu taleplerin karşılanmasında ise tarımda kullanılan geleneksel yöntemler yetersiz kalmaktadır. Talebin karşılanabilmesi ancak birim hayvan veya alandan en yüksek verim elde etmek ile mümkün olurken, bu durum ancak tarımsal üretimde yeniliklerle mümkün olacaktır. Özellikle tüketicilerin beklentilerini karşılayacak ve tercihlerine neden olacak ürünlerin üretilmesi için tarım sektöründe bir değişimin yaşanması gerekmektedir. Fakat tarımın yapısal, ekonomik ve çevresel sorunlarından dolayı bu değişim gecikmektedir. $\mathrm{Bu}$ değişimin yaşanması için ise üreticilerin girişimci özelliklerinin kazandırılması ve girişimciliği etkileyen faktörlerin belirlenerek bu yönde çözüm önerisi geliştirmek son derece önemlidir. Çünkü girişimcilik, sektördeki fırsatların belirlenmesi ile başlayıp üretim faktörlerinin planlı bir şekilde örgütlenmesiyle devam eden, bulunduğu sektörde işsizlik sorununa en önemli çözüm yolu olan ve özellikle ülkelerin veya bölgelerin yerel kalkınmadaki öncülüğünü oluşturan dinamik bir süreçtir. İşletmelerin küresel boyutta rekabet edebilmeleri için girişimcilik yenilik ve yaratıcılığın kaynağıdır. Girişimcilik sadece ekonomik düzeyde faaliyette bulunulması değil aynı zamanda sosyal bilincin oluşturulması ve refah düzeyinin arttırılmasına olanak sağlamaktadır. Girişimcilik eylemini gerçekleştiren girişimci ise, ekonomik kaynakların optimal kullanılmasını sağlayan ve bu kaynaklar ile pazar firsatları karşısında yeni fikirlerin oluşmasına imkan sağlayan kişidir (Yalçıntaş, 2010). Tüm bu sebeplerden dolayı girişimciler topluma karşı önemli görevler üstlenirler ve üstlendikleri görevlerle sektörel ekonomik büyüme ve kalkınmaya katkıda bulunurlar. Girişimci sağlayacağı bu önemli katkıları ise sektörel bazda farklılıklar göstermektedir. Nitekim sektörün rekabet gücü, sermaye yapısı, kârlılık düzeyi, girişimcinin sektörel bilgi ve deneyimi gibi sosyo- ekonomik birçok faktör yatırımların hangi sektörlerde olacağını belirleyen en önemli etkenlerdir. Bunların yanı sıra sektörlerde oluşacak firsatlar ve risklerin belirlenmesi de o sektörde girişimciliğin oluşmasında önemli bir payı vardır. Yapılan çalışmalarda girişimciliğin sektörlere göre dağılımında en az payın \%1 ile tarım sektöründe, \%34.64 ile de toptan ve perakende ticarette olduğu görülmektedir (Ağıan, 2018; TÜIK, 2018).

Tarım işletmeleri, gelişmekte olan ülkelerdeki istihdamın yaklaşık \%50'sini oluşturmaktadır (WorldBank, 2012). Bununla birlikte, bu işletmelerin çoğu insanları yoksulluktan kurtarmak için yeterli gelir sağlamamaktadır. Tarımla ilgili girişimcilik faaliyetleri, hanehalkı gelirlerini arttırmak ve geçiş ekonomileri bölgelerindeki kırılganlıkları azaltmak için bir çözüm üretmektedir (Singh, 2014). Bu çözüme rağmen sektördeki eğitim faaliyetlerinin, yönlendirmelerin ve desteklemelerin yetersiz olması girişimciliği sınırlandırmaktadır (Berglann ve ark., 2011).

Türkiye ekonomisinde en temel 4 sektörden (sanayi, hizmet ve inşaat) biri olan tarım sektöründe girişimcilik, firmadan daha çok üretici odaklı olması nedeniyle diğer sektörlerden farklı olması sağlamaktadır. Ayrıca tarım sektöründe risk ile belirsizliklerin fazla olması, kârlılığın az olması ve buna bağlı olarak sermaye devir hızının düşük olması girişimciliği engellemektedir. Ayrıca tarımın yapısal özelliklerinden kaynaklı arazilerin parçalı ve işletme ölçeklerinin küçük olması işletmelerin risk almalarını ve firsatları değerlendirememelerine neden olmaktadır. Çünkü gelişmiş ülkelerde tarımda girişimci faaliyetlerinin yaygınlaşmalarında en büyük faktör sermaye birikiminin yüksek olması ve buna bağlı olarak da yüksek karlılık düzeylerinin oluşması görülmektedir.

$\mathrm{Bu}$ kapsamda tarımsal girişimciliğin geniş bir perspektifte tanımları yapılmaktadır. Günlük dilde "girişimci" terimi, genellikle işletme sahibi, çalıştırıcı, serbest meslek sahibi bir kişi, tek tüccar veya çiftçi ile dolayısıyla karmaşık durum ile rol (belirli bir konumdaki davranış) arasında değiştirilebilir bir şekilde kullanılmaktadır (McClelland, 1967). Tarımsal girişimcilik alanında tanımlamalar ile ilgili olarak birçok farklı tanım bulunmaktadır. Ayrıca bazı tarımsal girişimcilik ile ilgili tanımlar, bireysel niteliklere (ör. Kontrol yerelliği, başarıya duyulan ihtiyaç) odaklanırken, tarımsal girişimci davranışlara tarımsal bilişlere ve tarımsal sermayeye yönelik olarak odaklanan tanımlamalarda mevcuttur. Son on yılda tarımsal girişim firsatlarının tanımlanması, değerlendirilmesi ve takip edilmesi (Shane ve Venkataraman, 2000) tarımsal girişimciliğin en temel ayırt edici bir özelliği olduğu gerçeği artmaktadır. (Müftüoğlu ve Ark., 2009). 
Tanımlardan da anlaşılacağı üzere girişimci düşüncenin temelinde dört bileşen bulunmaktadır. Bunlar; inovatif fikre sahip olma (yenilikçi ve yaratıcı olma), risk alabilmek, önder olma (öncü olma) ve rekabet sağlamadır. $\mathrm{Bu}$ bileşenlere sahip olan girişimciler toplumun gereksinimleri doğrultusunda hareket edecek olup, geleceğe yönelik karar almasında bu bileşenlerin alt boyutları incelenmiştir. $\mathrm{Bu}$ kapsamda tarım işletmelerinde bu bileşenler doğrultusunda ölçek geliştirilmiş ve girişimciliği etkileyen faktörler belirlenmiştir. Bugüne kadar yapılan çalışmalarda tarımsal girişimcilik uluslararası literatürde incelenmiş olup (Ghiasy ve ark., 2009b; Zachary ve Mishra, 2010; Lashgarara ve ark., 2011; Vakili ve ark., 2013; Olowa ve Olowa, 2015; Kumar, 2016) ulusal çalışmalar incelendiğinde ise tarım işletmelerine yönelik girişimcilik çalışmaları sınırlı olmuş (Çınar ve ark., 2017; Bayramoğlu ve ark., 2013; Ağızan, 2018) ve yapılan çalışmalar genellikle sosyal bilimler alanında gerçekleşmiştir (Ghiasy ve ark., 2009a; Onay ve Çavuşoğlu, 2010; Soleimanpour ve ark., 2011; Chandrashekar ve Bahal, 2014; Uysal, 2015; Arıkan, 2016; Öztürk, 2016). Türkiye tarım işletmelerinin girişimciliği etkileyen faktörlerin belirlenmesine yönelik herhangi bir çalışmaya literatürde rastlanılmamış olmasından ve sahip oldukları yapısal, sosyal ve ekonomik faktörlerin farklılık göstermesi nedeniyle dolayı çalışma bu yönüyle özgün bir yapı kazanmıştır.

Araştırma alanı olan Ereğli ilçesi Konya ilinde işlenen tarla arazisinin\%5.39'unu, nadas alanının \%6.55'ini, sebze alanının \%23.84'ünü ve meyve alanının \%10.52'lik kısmını kapsamaktadır. Ayrıca beyaz kiraz gibi coğrafi işaretli ürünlerin üretilmesi ve Türkiye süt üretiminde ilk sırada yer alması ilçede kırsal girişimcilik modellerinin geliştiğinin bir göstergesidir. Bölgede girişimciliği etkileyen faktörlerin belirlenmesi girişimciliğin yaygınlaştırılması açısından önemlidir. Girişimciliğin yaygınlaştırılması özellikle üretim faktörleri açısından zengin olan bölgelerde önem kazanmaktadır. Nitekim bu işletmelerde sermaye birikiminin daha yüksek olması, eğitim düzeyinin diğer bölgelere göre daha yüksek olması ve risk yönetim gibi stratejilerin kullanılması girişimciliğin oluşturulması açısından bakımından önemlidir. Bu kapsamda üretim faktörlerini bir araya getirerek organize edilmesine imkân sağlayan girişimciliğe etki eden faktörlerin belirlenmesi gerekmektedir.

\section{MATERYAL ve METOT}

Araştırmanın popülasyonunu Ereğli ilçesindeki tarla ürünleri tarımı yapan işletmelerin arazi miktarları oluşturmuş olup, örnek belirlemede ise tabakalı tesadüfi örnekleme yöntemi (Yamane, 1967) kullanılmıştır. Buna göre $\% 90$ güven sınırı ve $\% 5$ hata payı ile belirlenen 98 tarım işletmesi ile anket yapılmıştır.
Tarım sektörünün yapısı gereği bağımlı değişkeni tek bir değişkenle açıllamak mümkün olmamaktadır. $\mathrm{Bu}$ sebeple bağıml değişkenin üzerinde birden fazla bağımsız değişkenin etkisinin ölçülmesi amacıyla çoklu regresyon analizi yapılmıştır. Çoklu doğrusal regresyon analizi yapılırken bağımlı değişkenin sürekli veya sıralı verilerden oluşması gerekliliği dikkate alınmalıdır. Bağımsız değişkenler ise genellikle sayısal veriler olurken, cinsiyet ve eğitim gibi kategorik değişkenlerde modelde yer alabilmektedir. Modelde yer alan ve bağımlı değişken olarak belirlenen girişimcilik katsayısı 40 farklı değişken ile hesaplanmış ve bu değişkenler 5'li likert ölçeği yardımıyla sınıflandırılmıştır. Girişimcilik katsayısı hesaplanırken kullanılan değişkenler Çizelge 1'de verilmiştir. Bu kapsamda çalışmada kullanılan veri setinde girişimcilik katsayısı bağımlı değişken olarak ele alınmış, arazi miktarı, aktif sermaye, gayrisafi üretim değeri, EİB, yaş, sigorta yaptırma, net kar ve eğitim ise bağımsız değişken olarak kullanılmıştır.

Çalışma kapsamında modelde yer alan değişkenlerin hesaplanmasında ise tarım işletmelerinin sosyoekonomik özellikleri belirlenmiştir. Araştırmada tarım işletmelerinin nüfus, eğitim, işgücü, arazi varlıkları ve üretim desenleri belirlenmiştir. İşletmecilerin eğitim seviyeleri hesaplanırken 0-6 yaş nüfus hesaplamaya dahil edilmemiştir. Ayrıca erkek işgücü birimi hesaplanırken nüfus 7-14 yaş grubu erkeklerde 0.75 ve kadınlarda 0.50 katsayılar ile çarpılmış olup, 15-49 yaş grubu arasinda erkeklerde bu katsayı 1.00 ve kadınlarda 0.75 ve 50 ile daha yüksek yaşa sahip işletmelerde katsayılar erkeklerde 0.75 ve kadınlarda ise 0.50 olarak belirlenmiştir (Oğuz ve Bayramoğlu, 2018).

Araştırma kapsamında tarım işletmelerinin sermaye yapıları fonksiyona göre sınıflandırılmıştır. Modelde yer alan bir değişken olan gayrisafi üretim değeri işletmede üretilen bitkisel ve hayvansal ürünlerin toplamı ile her bir ürünün fiyatının çarpılmasıyla elde edilen değerdir. Ayrıca gayrisafi üretim değerine Prodüktif Demirbaş Kıymet Artışı (PDKA) dahil edilmiştir. Gayrisafi üretim değerinin hesaplanması işletmenin başarısının gösteren bir değer olarak bilinmektedir. Modelde yer alan net kâr değişkeni ise gayrisafi hasıladan toplam üretim masraflarının çıkartılmasıyla elde edilen değer olarak belirlenmektedir. Burada önemli olan kısım ise gayrisafi hasıla ve üretim masraflarının hesaplanmasıdır. Gayrisafi hasıla içerisinde gayrisafi üretim değerini, konut kira bedelini ve işletme dışı tarımsal gelir yer alırken, üretim masrafları toplam işletme masraflarından ve aktif sermayenin faizinin toplamından oluşmaktadır. Gayrisafi üretim değeri ve net kârda aynı şekilde işletmelerin karşılaştırılması için dekara düşen miktarları modelde kullanılmış ve sonuçlar analiz edilmiştir (Bayramoğlu ve ark., 2014). 
Çizelge 1.Girişimcilik Katsayısı Değişkenlerine Ait Skorlar

\begin{tabular}{|c|c|c|c|c|c|}
\hline Değişkenler & 1 & 2 & 3 & 4 & 5 \\
\hline Aile Bireylerinin Çalışması \% & $0-20$ & $21-40$ & $41-60$ & $61-80$ & $81-100$ \\
\hline Anıza Direk Ekim Makinası & $0-20$ & $21-40$ & $41-60$ & $61-80$ & $81-100$ \\
\hline Barınak Modernizasyonu \% & $0-20$ & $21-40$ & $41-60$ & $61-80$ & $81-100$ \\
\hline Biyoyakıt Kullanımı & $0-20$ & $21-40$ & $41-60$ & $61-80$ & $81-100$ \\
\hline Borç /Sermaye Oranı \% & $0-20$ & $21-40$ & $41-60$ & $61-80$ & $81-100$ \\
\hline Daimî İşüüü Çalıştırma \% & $0-20$ & $21-40$ & $41-60$ & $61-80$ & $81-100$ \\
\hline Deneyim (Yll) & $10-15$ & $16-20$ & $21-25$ & $26-30$ & $31^{-+}$ \\
\hline Desteklemeler (Bin TL) & $1-5$ & 6-10 & $11-15$ & $16-20$ & $21^{-+}$ \\
\hline Diğer Üreticilerle Işs birliği \% & $0-20$ & $21-40$ & $41-60$ & $61-80$ & $81-100$ \\
\hline Eğitim & Lisans & Ônlisans & Lise & Ortaokul & İlk \\
\hline Fuara Katılım Ve Sıklığı (Yıl) & 1 & 2 & 3 & 4 & 5 \\
\hline İș Bölümü Ve Uzmanlaşma \% & $0-20$ & $21-40$ & $41-60$ & $61-80$ & $81-100$ \\
\hline İş Planlaması \% & $0-20$ & $21-40$ & $41-60$ & $61-80$ & $81-100$ \\
\hline Karar Verme (Yıl) & $10-15$ & $16-20$ & $21-25$ & $26-30$ & $31^{-+}$ \\
\hline Kayıt Tutma \% & $0-20$ & $21-40$ & $41-60$ & $61-80$ & $81-100$ \\
\hline Konferans Takibi Ve Sıklığı (Yıl) & 1 & 2 & 3 & 4 & 5 \\
\hline Kredi Kullanma \% & $0-20$ & $21-40$ & $41-60$ & $61-80$ & $81-100$ \\
\hline Makine Ve İşgücünde Yardımlaşma \% & $0-20$ & $21-40$ & $41-60$ & $61-80$ & $81-100$ \\
\hline Ortağa Ve Kiraya Arazi İşleme \% & $0-20$ & $21-40$ & $41-60$ & $61-80$ & $81-100$ \\
\hline Ortalama Traktör Yaşı & $0-5$ & 6-10 & 11-15 & $16-20$ & $20^{-+}$ \\
\hline Öz sermaye/Pasif Oranı \% & $0-20$ & $21-40$ & $41-60$ & $61-80$ & $81-100$ \\
\hline Pinomatik Ekim Makinesi\% & $0-20$ & $21-40$ & $41-60$ & $61-80$ & $81-100$ \\
\hline Sigorta Yaptırma \% & $0-20$ & $21-40$ & $41-60$ & $61-80$ & $81-100$ \\
\hline Soğuk Hava Deposu\% & $0-20$ & $21-40$ & $41-60$ & $61-80$ & $81-100$ \\
\hline Sorun Çözme \% & $0-20$ & $21-40$ & $41-60$ & $61-80$ & $81-100$ \\
\hline Sözleşmeli Üretim \% & $0-20$ & $21-40$ & $41-60$ & $61-80$ & $81-100$ \\
\hline Sulama Sistemleri\% & $0-20$ & $21-40$ & $41-60$ & $61-80$ & $81-100$ \\
\hline Sulu Arazi Oranı (\%) & $0-20$ & $21-40$ & $41-60$ & $61-80$ & $81-100$ \\
\hline Suni Tohumlama \% & $0-20$ & $21-40$ & $41-60$ & $61-80$ & $81-100$ \\
\hline Teknik Bilgiye Dayalı Girdi Kullanımı \% & $0-20$ & $21-40$ & $41-60$ & $61-80$ & $81-100$ \\
\hline Toprak Analizi Yaptırma \% & $0-20$ & $21-40$ & $41-60$ & $61-80$ & $81-100$ \\
\hline Toprak İşlemesiz / Azaltılmış Tarım \% & $0-20$ & $21-40$ & $41-60$ & $61-80$ & $81-100$ \\
\hline Üretim Planında Değişiklik Yapma \% & $0-20$ & $21-40$ & $41-60$ & $61-80$ & $81-100$ \\
\hline Ürün Çeşitliliği & $1-2$ & $3-4$ & $5-6$ & $7-8$ & $9-10$ \\
\hline Ürün Pazarlaması \% & $0-20$ & $21-40$ & $41-60$ & $61-80$ & $81-100$ \\
\hline Yabancı İşgücü Çalıştırma \% & $0-20$ & $21-40$ & $41-60$ & $61-80$ & $81-100$ \\
\hline Yaş (Yıl) & $20-30$ & $31-40$ & $41-50$ & $51-60$ & $61^{-+}$ \\
\hline Yatırım Kararları Ve Hedefleri \% & $0-20$ & $21-40$ & $41-60$ & $61-80$ & $81-100$ \\
\hline Yazılı Ve Görsel Yayın Takibi \% & $0-20$ & $21-40$ & $41-60$ & $61-80$ & $81-100$ \\
\hline Yeni Tarım Sistemleri \% & $0-5$ & $6-10$ & $11-15$ & $16-20$ & $21^{-+}$ \\
\hline
\end{tabular}

Kaynak: Ağıan (2018)

Y: Girişimcilik Katsayısı $=\mathrm{X}_{1}$ : Arazi miktarı, $\mathrm{X}_{2}$ : Dekara Aktif Sermaye, $\mathrm{X}_{3}$ : Dekara Gayrisafi Üretim Değeri (GSÜD), $\mathrm{X}_{4}$ : Erkek İşgücü Birimi (EİB), X5: Tarım İşletmecisi Yaşı, $X_{6}$ : Sigorta Yaptırma, $X_{7}$ : Dekara Net Kar, $X_{8}$ : Eğitim

\section{BULGULAR ve TARTIŞMA}

Araştırma bölgesinde yer alan tarım işletmelerin girişimcilik katsayısı, 40 farklı değişken ve 5’li likert ölçeği yardımıyla hesaplanmıştır. Buna göre tarım işletmelerinin girişimcilik katsayısının ortalaması 3.75 olarak hesaplanmıştır. Bu ortalamanın altında kalan tarım işletmelerinin girişimci olmadıkları belirlenmiştir. Elde edilen sonuçlara göre tarım işletmelerinin \%47.95' $\mathrm{i}$ girişimci, \%52.05'in ise girişimci olmadığı bulunmuştur. Elde edilen sonuçlar itibariyle her bir işletmenin girişimcilik katsayısı belirlenmiş ve bağımlı değişken olarak bu ölçekler modele dahil edilmiştir.

Modele dahil edilmek üzere tarımsal üretim faaliyetinde bulunan üreticilerin demografik yapıları incelenmiş ve Çizelge 2'de gösterilmiştir. İşletme başına ortalama nüfus varlığı 4.77 kişi olarak belirlenmiştir. $\mathrm{Bu}$ durum işletme grupları arasında farklılık göstermektedir. 0-50 da araziye sahip olan küçük ölçekli işletmeler de ortalama nüfus varlığı 3.25 
kişi 51-150 da araziye sahip olan orta ölçekli işletmelerde ortalama nüfus varlığ 4.38 kişi ve 151 ve daha fazla dekar araziye sahip olan büyük ölçekli işletmelerde ise ortalama nüfus varlığı 5.19 kişi olarak belirlenmiştir. Nüfus varlığının yüksek olması üretim faktörlerinden biri olan işgücünü olumlu etkileyecektir. Özellikle üretim faktörlerinin yapısı ve sayısı sektörün gelişmişliği ile yakından ilgili olması açısından işgücü arzının kaynağı olarak nüfus tarım işletmelerinde önem ifade etmektedir. Ayrıca bir sektördeki nüfus varlığının çok veya az olması sektörün gelişmişlik düzeyi ile yakından ilişkilidir. Eğer sektördeki nüfus işsizliğe neden olmuyorsa sektördeki nüfus artışı yararlı olabilecektir. Fakat Türkiye tarım işletmelerinde birçok ekonomik, sosyal ve çevresel faktörlerden dolayı diğer sektörlere geçiş görülmektedir. Nitekim tarım sektöründe 2000 yılında tarımın istihdamdaki oranı \%36 iken, 2017 yılında \%19.4 gerilemiş olup, yıllar itibariyle istihdamın azaldığı görülmektedir (Bayramoğlu ve Bozdemir, 2018; TOB, 2018). Bu sebeple kırsal nüfusun tarımda kalabilmesi için sadece ekonomik tedbirlerin yanı sıra aynı zamanda sosyal ve çevresel önlemleri kapsayıcı bir politikanın gerçekleştirilmesi son derece gereklidir. Tarım işletmelerindeki nüfusun cinsiyete göre dağılımı da Çizelge 2'de yer almaktadır. Tarım işletmelerinde hanehalkı içerisinde nüfus dağılımı ise \%53.66 erkek, \%46.34'ü kadın olarak belirlenmiştir. $\mathrm{Bu}$, her iki cinsiyetin bölgede tarımsal üretimde yer aldığını, ancak erkeklerin daha büyük bir orana sahip olduğunu göstermektedir. Nitekim tarım işletmelerinde yönetim kararlarının önemli bir kısmını erkekler vermektedir. Bu durum erkeklerin toprak edinimi ve diğer üretim faktörleri gibi konularda kadınlara karşı sahip oldukları geleneksel hakimiyet haklarina atfedilebilmektedir (Esiobu ve Ibe, 2015). Ayrıca, tarım sektöründe daha fazla erkek sahibi olmak, girişimcilik gelişimi için önemlidir. Çünkü erkekler tarım işletmelerinin bazı enerji ve risk gerektiren girişimlerini üstlenmeye daha hazır olma eğilimindedir (Esiobu ve ark., 2014).

Çizelge 2.Tarım İşletmelerinin Demografik Özellikleri

\begin{tabular}{|c|c|c|c|c|c|c|c|c|c|}
\hline \multirow{2}{*}{\multicolumn{2}{|c|}{ İşletme Büyüklüğü (dekar) }} & \multicolumn{2}{|l|}{$0-50$} & \multicolumn{2}{|c|}{$51-150$} & \multicolumn{2}{|c|}{$151-+$} & \multicolumn{2}{|c|}{ İşletme Ort. } \\
\hline & & Adet & $\%$ & Adet & $\%$ & Adet & $\%$ & Adet & $\%$ \\
\hline \multirow{4}{*}{ Nüfus } & $0-6$ & 0.13 & 3.85 & 0.31 & 7.14 & 0.72 & 13.95 & 0.54 & 11.35 \\
\hline & $7-14$ & 0.63 & 19.23 & 0.5 & 11.43 & 0.74 & 14.29 & 0.65 & 13.70 \\
\hline & $15-49$ & 1.25 & 38.46 & 2.38 & 54.29 & 2.97 & 57.14 & 2.63 & 55.25 \\
\hline & $50^{-+}$ & 1.25 & 38.46 & 1.19 & 27.14 & 0.76 & 14.62 & 0.94 & 19.70 \\
\hline \multirow{3}{*}{ EIB } & 7-14 & 0.31 & 13.89 & 0.25 & 8.04 & 0.37 & 10.76 & 0.33 & 10.09 \\
\hline & $15-49$ & 1.13 & 50.00 & 2.11 & 67.84 & 2.59 & 75.34 & 2.32 & 71.55 \\
\hline & $50-+$ & 0.81 & 36.11 & 0.75 & 24.12 & 0.48 & 13.89 & 0.59 & 18.36 \\
\hline \multirow{2}{*}{ Cinsiyet } & Erkek & 1.88 & 57.84 & 2.38 & 54.33 & 2.76 & 53.17 & 2.56 & 53.66 \\
\hline & Kadın & 1.38 & 42.16 & 2.00 & 45.67 & 2.43 & 46.83 & 2.2 & 46.34 \\
\hline \multirow{6}{*}{ Eğitim } & Okuryazar & 0.00 & 0.00 & 0.03 & 0.77 & 0.02 & 0.39 & 0.01 & 0.48 \\
\hline & Okuryazar Değil & 0.13 & 4.00 & 0.00 & 0.00 & 0.09 & 1.93 & 0.06 & 1.45 \\
\hline & Ilkokul & 2.25 & 72.00 & 2.28 & 56.15 & 2.26 & 50.58 & 2.27 & 53.62 \\
\hline & Ortaokul & 0.38 & 12.00 & 0.72 & 17.69 & 0.59 & 13.13 & 0.61 & 14.49 \\
\hline & Lise & 0.25 & 8.00 & 0.78 & 19.23 & 1.10 & 24.71 & 0.93 & 21.98 \\
\hline & Üniversite & 0.13 & 4.00 & 0.25 & 6.15 & 0.41 & 9.27 & 0.34 & 7.97 \\
\hline
\end{tabular}

Girişimciliğinin temel bileşenlerinden biri olan rekabetçi düşüncenin tarım işletmelerinde uygulanabilir olabilmesi için eğitim düzeyinin yüksek olması gerekmektedir. Tarım işletmelerinin yapısı gereği işletme sahipleri işletmenin yöneticisi pozisyonunda olması ve girişimci yaklaşımla üretimde bulunmaması işletmenin kârlılığını etkilemektedir. Tarım işletmelerinin sahiplerinin yöneticiden çok girişimci kimliğine sahip olması ve devamında eğitim düzeyinin yüksek olması üretiminin başarısını etkilemektedir. Özellikle tarım işletmelerinde bilginin varlığı, düzeyi ve kullanımı işgücünün etkinliğini ve dolayısıyla girişimci tarafından alınan kararlarının etkinliğini arttırmaktadır (Bayramoğlu ve ark., 2014). İncelenen işletmelerde eğitim düzeyi incelenmiş ve küçük ölçekli işletmelerde ilkokul mezunu kişilerin oranı \%72.00 iken orta ölçekli işletmelerde \%56.15 ve büyük ölçeli işletmelerde \%50.58 olarak hesaplanmıştır. Ayrıca işletme ölçeği büyüdükçe lise ve üniversite mezunlarının oranları yükseldiği görülmektedir. $\mathrm{Bu}$ durumda işletme ölçeğinin ve eğitim düzeyinin artması işletmelerde kaynakların daha etkin kullanılmasını sağladığı söylenebilmektedir. Dolayısıyla işletme ölçeğine ve eğitim düzeyine bağlı olarak verimlilik artmaktadır. Nitekim bölgede yapılan diğer çalışmalarda elde edilen veriler bu sonucu desteklemektedir (Bayramoğlu, 2013; Bozdemir, 2017; Oğuz ve ark., 2017).

İncelenen işletmelerde girişimciliği etkileyen bir diğer faktör olan arazinin kullanımına ilişkin üretim deseni Çizelge 3'de verilmiştir. Buna göre küçük ölçekli işletmelerde ortalama işletme büyüklükleri 32.75 da 
olup, bu durum orta ölçekli işletmelerde 98,03 da ve büyük ölçekli işletmelerde ise 277.98 da olarak belirlenmiştir. Arazi büyüklüğünün girişimcilik üzerindeki etkisi yüksek olmakla birlikte yapılan analizler sonucunda da bu durum görülmüştür. Nitekim geniş bir üretim desenine sahip olunması işletme içerisinde gelirin yll içerisinde düzenli bir şekilde dağılmasına yardımcı olmaktadır. Ayrıca farklı üretim sistemlerinin kullanılması ve üretim faaliyetlerinin çeşitlendirilmesi açısından üretim boyunca oluşacak olan riskleri dağıtmak ve bu yönde minimize etmek son derece önemlidir. Tarım sektöründe ortaya çıkacak olan riskleri üstlenen girişimci yapısı gereği tarımda bu riskleri üstlenmeli ve üretim faktörlerini organize etmelidir. Bu noktada üretim faaliyetlerinin hangisini işletmesinde kullanacak olmasını seçmesi girişimcinin başarısını etkileyecektir.

Çizelge 3.Incelenen İşletmelerde Üretim Deseni, Ortalama Parsel Sayısı ve Büyüklüğü

\begin{tabular}{llllll}
\hline İsletme Büyüklüğü (dekar) & & $0-50$ & $51-150$ & $151^{-+}$ & İşletmeler Ortalaması \\
\hline \multirow{2}{*}{ Tarla ürünleri Üretim Alanı } & Dekar & 26.50 & 93.19 & 247.57 & 179.11 \\
\cline { 2 - 6 } & $\%$ & 80.92 & 95.06 & 89.06 & 89.91 \\
\hline \multirow{2}{*}{ Sebze Üretim Alanı } & Dekar & 6.25 & 2.97 & 23.14 & 15.17 \\
\cline { 2 - 6 } & $\%$ & 19.08 & 3.03 & 8.32 & 7.620 \\
\hline \multirow{2}{*}{ Meyve Üretim Alanı } & Dekar & 0.00 & 1.88 & 7.28 & 4.920 \\
\cline { 2 - 6 } & $\%$ & 0.00 & 1.91 & 2.62 & 2.470 \\
\hline \multirow{2}{*}{ Toplam Üretim Alanı } & Dekar & 32.75 & 98.03 & 277.98 & 199.20 \\
\hline Ortalama Parsel Sayısı & Dekar & 100.00 & 100.00 & 100.00 & 100.00 \\
\hline Ortalama Parsel Büyüklüğü & Dekar & 14.56 & 3.56 & 3.81 & 3.60 \\
\hline
\end{tabular}

Sektörel olarak tarım işletmesi en küçük birim olarak kabul edildiğinden dolayı başarı kriterleri işletmeci ve işletme üzerinden gerçekleşmektedir. Bununla birlikte tarım sektörünün uzun bir üretim süresine sahip olmasıyla birlikte üretim sonunda işletme ve işletmecilik anlamında bir başarı kriterleri mevcuttur. Nitekim üretim faaliyetleri gerçekleşmeden ne etkinlikten ne de başarı kriterlerinden bahsetmek mümkün değildir. Tarım işletmeleri genel ekonomideki bir firma olarak düşünüldüğünde üretim bölümlerine ayrılmakta ve her bir üretim faaliyetlerinin başarı kriterleri ile incelenmesi mümkün olmaktadır. Özellikle kullanılan üretim faktörlerinin etkinliği işletmenin başarısını etkilemektedir. İşgücünün başarısı, sermayenin başarısı ve müteşebbis başarısı gibi farklı başarı kriterleri tarımda kullanılmaktadır.

$\mathrm{Bu}$ çalışma kapsamında da işletmelerin başarı kriterlerinin ortaya konulması açısından işletmelerin yıllık faaliyet sonuçları incelenmiş ve işletme gruplarına göre karşılaştırılması yapılmıştır. $\mathrm{Bu}$ amaca yönelik olarak çalışma kapsamında incelenen işletmelerin yıllık faaliyet sonuçları dekara düşen değerler cinsinden verilmiştir. Yapılan analiz sonucunda dekara düşen aktif sermaye miktarı ve işletme masrafları işletme ölçeği büyüdükçe düştüğü görülmektedir. Nitekim bu durum işletmelerin ölçeklerinin büyüdükçe sermayelerini daha rasyonel kullandıklarını göstermektedir. Çizelge 4'de yer alan diğer göstergelerde ise durum farklı olmakla birlikte işletme ölçeği büyüdükçe dekara düşen gayrisafi üretim değeri, gayrisafi hasıla, saf hasıla, brüt kâr, net kâr ve tarımsal gelir miktarı artmaktadır. Bu değerlerin artmasının girişimcilik üzerindeki etkisinin belirlenmesi çalışmanın amacını oluşturmaktadır.

Bu amaca yönelik olarak işletmelerin sosyo-ekonomik faktörlerin girişimcilik üzerindeki etkisini belirlemek için doğrusal regresyon analizi kullanılmıştır. Çalışmada veriler belirli bir ölçüm, tartım veya araç kullanılarak elde edilen veriler olup, bu verilerin bir birimi vardır. $\mathrm{Bu}$ verilere metrik/sürekli/ölçülmüş veriler adı verilmekte olup, çalışma kapsamında bağımlı değişkenin sürekli veri olmasından dolayı doğrusal regresyon analizi kullanılmıştır. Doğrusal regresyon analizinde modelin yeterliliğini belirlemek için varyans analizi ve $\mathrm{R}^{2}$ 'ye bakılmaktadır. Modelde $\mathrm{R}^{2} 0.775$ olarak belirlenmiştir (Çizelge 5).

Bu sonuca göre bağımsız değişkenlerde meydana gelen değişme bağıml değişkenin \%77.50'sini ifade ettiği belirlenmiştir. Diğer bir ifadeyle arazi miktarı, aktif sermaye, gayrisafi üretim değeri, EİB, yaş, sigorta yaptırma, net kar ve eğitim değişkenlerinde meydana gelen değişimin girişimcilik katsayısının \%77.50'sini açıklamaktadır.

F testi bağımlı değişkenin bağımsız değişkenler tarafından açıklanıp açıklanmadığını bir diğer değişle değişkenler arasında doğrusal bir ilişki olup olmadiğını test etmektedir. Varyans analizinde F istatistiği ve bunun anlamlılık düzeyini gösteren Sig. değeri model için önemlidir. Nitekim F değerinin istatistiki olarak \%1 önem seviyesinde anlamlı olduğu görülmüştür. 
Çizelge 4.İncelenen İ̧̧letmelerin Yıllık Faaliyet Sonuçları (TL/da)

\begin{tabular}{|c|c|c|c|c|}
\hline \multirow{2}{*}{ İşletme Büyüklüğü (dekar) } & $0-50$ & $51-150$ & $151-+$ & İsletmeler Ort. \\
\hline & Dekara & Dekara & Dekara & Dekara \\
\hline Aktif Sermaye & $11.582,76$ & $9.895,60$ & $7.709,85$ & $8.113,06$ \\
\hline Gayrisafi Üretim Değeri & $1.376,88$ & $1.533,04$ & $1.556,08$ & $1.549,27$ \\
\hline Gayrisafi Hasıla & $1.508,18$ & $1.644,53$ & $1.650,14$ & $1.646,63$ \\
\hline İंşletme Masrafları & $1.340,41$ & $1.103,58$ & 851,88 & 898,88 \\
\hline Saf Hasıla & 167.77 & 540.96 & 798.26 & 747.75 \\
\hline Brüt Kâr & 589.84 & 847.70 & 931.12 & 912.43 \\
\hline Net Kâr & -411.37 & 46.18 & 412.77 & 342.10 \\
\hline Tarımsal Gelir & 313.60 & 650.70 & 856.94 & 815.80 \\
\hline Tarımsal Gelir (Nüfus Başına) & $3.160,10$ & $14.580,23$ & $45.901,56$ & $34.102,80$ \\
\hline Toplam Aile Geliri (Nüfus Başına) & $3.746,36$ & $15.195,77$ & $46.812,33$ & $34.907,00$ \\
\hline Rantabilite Faktörü (İşletme başına) \% & 11.12 & 32.89 & 48.38 & 45.41 \\
\hline Mali Rantabilite (İsletme bassına) \% & -3.97 & 0.52 & 6.16 & 4.83 \\
\hline Ekonomik Rantabilite (İşletme başına) \% & 1.45 & 5.47 & 10.3 & 9.2 \\
\hline Sermaye Devir Oranı (İşletme başına) \% & 11.89 & 15.49 & 20.18 & 19.1 \\
\hline Sermave Devir Hızı (İsletme basına) & 8.41 & 6.45 & 4.95 & 5.24 \\
\hline
\end{tabular}

Çizelge 5.Çoklu Doğrusal Regresyon Modeli Sonuçları

\begin{tabular}{|c|c|c|c|c|c|c|}
\hline \multirow{2}{*}{ Model } & \multicolumn{2}{|c|}{ Standartlaştırılmamış Katsayılar } & \multirow{2}{*}{ t } & \multirow{2}{*}{$\begin{array}{l}\text { Önem } \\
\text { Düzeyi }\end{array}$} & \multicolumn{2}{|c|}{ Doğrusallık İstatistikleri } \\
\hline & B & Std. Sapma & & & Hata Payı & VIF \\
\hline (Constant) & 3.490 & 0.177 & 19.732 & 0.000 & & \\
\hline ALAN & 0.001 & 0.000 & 2.787 & 0.007 & 0.488 & 2.051 \\
\hline AKTDR & $-2.19 \mathrm{E}-05$ & 0.000 & -2.480 & 0.015 & 0.659 & 1.516 \\
\hline GSUDDR & 0.000 & 0.000 & 5.064 & 0.000 & 0.559 & 1.789 \\
\hline EIB & 0.09 & 0.026 & 3.462 & 0.001 & 0.554 & 1.804 \\
\hline YAS & -0.007 & 0.002 & -2.947 & 0.004 & 0.638 & 1.566 \\
\hline SGRTYAP & 0.167 & 0.071 & 2.361 & 0.020 & 0.795 & 1.257 \\
\hline NKDR & 0.000 & 0.000 & 2.510 & 0.014 & 0.612 & 1.634 \\
\hline EGTM & 0.036 & 0.028 & 1.320 & 0.190 & 0.872 & 1.146 \\
\hline
\end{tabular}

Çizelge yer alan bir diğer gösterge ise Durbin Watson (DW) katsayısı olup, bu katsayının 1.5-2.5 arasında bir değere sahip olması beklenmektedir.

Çalışma kapsamında DW 1.623 olarak hesaplanmış ve çalışmada herhangi bir otokorelasyon probleminin olmadığını ve parametrelerin etkin olduğu belirlenmiştir Ayrıca çalışma kapsamında modelde çoklu bağlantı probleminin olup olmadığının belirlenmesine yönelik VIF değeri hesaplanmıştır. VIF değeri 5'den küçük olduğu zaman modelde herhangi bir çoklu bağlantı probleminin olmadığının bir göstergesidir (Kalaycı, 2010). Cizelge 5'de modelde yer alan değişkenlere ait katsayıların tahmini değerleri ve bunlara ilişkin $\mathrm{t}$ değerleri yer almaktadır. Burada eğim değişkenininki hariç olmak üzere $t$ değerlerinin istatistiki olarak anlamlı olduğu belirlenmiştir. Girişimciliği etkileyen faktörler arazi miktarı, dekara aktif sermaye, dekara gayrisafi üretim değeri, erkek işgücü birimi, yaş, sigorta yaptırma durumu, dekara net kar ve eğitim düzeyi olarak belirlenmiştir. Buna göre arazi değişkeninin işareti pozitif olarak belirlenmiştir. Arazi miktarı arttıkça girişimciliğin katsayısının arttığı belirlenmiş olup beklenen bir durumdur. Nitekim arazi bir üretim faktörü olarak yer almakta olup üretim faktörleri arasında organizasyonu sağlayacak olan kişi müteşebbis yani girişimcidir. Ayrıca tarım işletmelerinin ekonomik performansları değerlendirildiğinde büyük arazilere sahip işletmelerde girişimcilik katsayısının yüksek olduğu görülmektedir(Ağızan, 2018). Özellikle tarım işletmelerinde işletme ölçeğinin artmasına bağlı olarak üretimde çeşitlilik sağlanacak ve gelirin yıl içerisindeki dağılımının düzenlenmesine yardımcı olacaktır. Üretim faktörleri arasında yer alan işgücünü ise modelde erkek işgücü birimi (EİB) temsil etmektedir. İşücü sadece fiziksel olarak değil aynı zamanda düşünsel çaba olarak da ifade edilmektedir. $\mathrm{Bu}$ bakımdan büyük ölçekli işletmelerde üretim çeşitliliğinin sağlanması ve farklı üretim kollarında faaliyet gösterilmesi sonucunda EİB yükselmektedir. $\mathrm{Bu}$ durum modelde pozitif olarak görülmektedir. EİB'nin artmasıyla birlikte üreticilerin girişimci katsayıları yükselmektedir. Bu durum aynı zamanda işgücünde ihtisaslaşmayı da beraberinde getirmektedir. Nitekim tarım işletmelerinde işgücü her üretim faaliyetiyle ilgilenmek zorunda olup, üretimde ihtisaslaşma bu nedenle sağlanamamaktadır. $\mathrm{Bu}$ kapsamda işgücünün 
ihtisaslaşması beraberinde girişimciliği de artıracaktır. Modelde yer alan diğer bir üretim faktörü ise sermayedir. Tarım işletmelerinde üretim üzerinde en büyük sınırlayıcı faktör olan sermaye, işletmelerin girişimciliğini de etkilemektedir. Nitekim üretim olmazsa, bir girişimden de söz edilmesi mümkün görülmemektedir. Özellikle bir yeni ürünün buluşunu yapandan çok, bu ürüne katma değer katarak pazara sunan bireyler başarılı ve girişimci kimlik kazanmaktadır. $\mathrm{Bu}$ nedenle sermayenin rolü bu noktada ortaya çıkmakta olup, sermayenin rasyonel kullanılması girişimciliği artıracağı sonucuna birlikte ulaşılmaktadır. Çizelge 3'de işletme ölçeklerine göre aktif sermayenin dekara düşen miktarları verilmiştir. Buna göre işletme ölçeği büyüdükçe dekara aktif sermaye kaynak kullanım etkinliğinden dolayı azalmaktadır. Ayrıca yapılan çalışma ile incelenen işletmeler arasında büyük ölçekli işletmelerin \%81'inin ortalama girişimcilik düzeyi olan 3.75 'den büyük olduğu ve girişimci olarak kabul edilmektedir. $\mathrm{Bu}$ nedenle dekara aktif sermaye azaldıkça girişimcilik katsayısı artması beklenen bir durumdur. $\mathrm{Bu}$ durum yapılan regresyon modeli ile de doğrulanmaktadır. Nitekim modelde sermayeyi temsilen dekara aktif sermaye miktarı dahil edilmiş ve dekara aktif sermaye miktarı azaldıkça girişimciliğin yükseldiği belirlenmiştir.

Üretim faktörleri dışında girişimciliği etkileyen sosyal faktörler olduğu belirlenmiştir. Girişimcilik katsayısını etkileyen en önemli faktörlerden birisi de üreticinin yaşıdır. Yaş değişkeninin işareti negatif olarak tespit edilmiştir. Buna göre genç yaşta olan üreticiler daha fazla girişimci oldukları görülmektedir. Özellikle genç yaşta olan üreticilerin yeniliklere daha yatkın olduğu bilinmektedir. Yenilikleri benimsemede girişimciliğin bir bileşeni olduğundan dolayı ve bu değişkenin ortalama katsayısının işletmelerin ölçeğinin büyümesiyle birlikte arttığı bilinmektedir. $\mathrm{Bu}$ anlamda girişimci kişilerin genç üreticilerin olduğu görülmektedir. $\mathrm{Bu}$ durum devlet politikalarında da dikkat çekmiş ve genç çiftçi gibi projeler hayata geçmiştir. Genç nüfusun tarıma tekrar dönmesi adına yapılan bu projelerin önemi yüksek olmakla birlikte etkinlikleri tartışılmaktadır. Nitekim verilen desteklemelerin yetersiz olduğu ve özellikle girdi maliyetlerinin yüksek olduğu bu dönemlerde bu projelerin etkinliklerinin belirlenmesi gerekmektedir. $\mathrm{Bu}$ projelerin ekonomiye olan katkıları elbette önemli olmakla birlikte tarım işletmelerinin sürdürülebilirliğinin sağlanmasında bu projelerin izlenebilirliklerinin sağlanması ön planda yer almalıdır.

Girişimciliği etkileyen bir diğer sosyal faktörler arasında eğitim yer almaktadır. Nitekim eğitim seviyesinin artması üreticilerin bilinç düzeylerini arttığı birçok çalışmada ortaya konulmuş olup bu çalışma kapsamında da eğitim seviyesinin girişimcilik üzerinde pozitif bir etkisinin olduğu belirlenmiştir (Balaban ve Özdemir, 2008; İpçioğlu ve Taşer, 2009; Bozkurt ve Alparslan, 2013; Duran ve ark., 2013; Bal ve ark., 2016; Uygun ve Güner, 2016; Kerse ve ark., 2017). Tarım sektöründe faaliyet gösteren işletmelerin \%53.62'si ilkokul mezunu olduğu belirlenmiş ve özellikle küçük ölçekli işletmelerde bu oran \%70'lere yükselmektedir. Büyük ölçekli işletmelerde ise lise ve üniversite mezunu kişi sayısının ortalaması daha yüksek olduğu tespit edilmiştir. Bu nedenle genç ve eğitim seviyesi yüksek olan bireylerin tarım sektörüne geçişini hızlandırmaya yönelik politikaların uygulanması bu konuda önemlidir. Ayrıca tarım sektöründe faaliyet gösteren işletmecilerin önemli bir bölümü 40 ve üzeri yaş seviyesinde yer almaktadır. Bu durumda eğitim seviyesinin artırılması ancak verilecek olan eğitimlerle birlikte algı oluşturmaya yönelik olacaktır. Bu kapsamda tarım işletmecilerini ve sektör dışından yeni yatırımcıları tarım sektörüne yönlendirecek eğitim faaliyetlerinin yapılması önemlidir. Yapılan çalışmalarda eğitim almış bireylerin daha farklı bakış açılarına sahip oldukları ve yeni yatırımlara yönlendirildikleri görülmektedir. Fakat bu konuda önemli olan eğitimin teoriye ve uygulamaya yönelik olmasıdır. Eğitim veren kişilerin düşük profilli olması, saha uygulamalarının yetersiz olması, demonstrasyon ile başarılı çiftçi örneklerinin yetersiz olması ve ders içeriklerinin teoriye uygun olmaması gibi nedenler eğitim faaliyetlerinin başarısız olmasına neden olmuştur. $\mathrm{Bu}$ nedenle tarım sektöründe faaliyet gösterecek olan yatırımcılara yönelik eğitim içeriklerinin teoriye ve uygulamaya yönelik olması girişimcilerin başarısını artıracaktır.

Tarım işletmelerinde girişimciliği etkileyen en önemli faktörlerden birisi de risklere karşı uygulanan sigortalılık durumudur. Risk alma girişimciliğin belki de en önemli bileşeni olarak değerlendirilmektedir. Fakat buradaki önemli olan nokta girişimcilikte her türlü riskten ziyade kabul edilebilir bir düzeyde bir risk faktörünün kabul edilebilirliğinden söz edilmelidir. Tarım sektöründe risklerin ve belirsizliklerin fazla olması firsatların algılanması konusunda da engel teşkil etmektedir. Çünkü risk alırken aynı zamanda ortaya çıkacak olan fırsatların da değerlendirilmesi girişimciliğin bir getirisi olarak bilinmektedir. Bu firsatların değerlendirilmesinde ise risk yönetim araçlarının uygulanması yer almaktadır. Günümüzde ise kullanılan en önemli risk yönetim aracı ise sigortadır. Sigortanın üreticilerin herhangi bir risk karşısında üretimde sürdürülebilirliklerini sağlanması açısından önemlidir. Ayrıca işletme ölçeklerinin büyümesiyle birlikte üretim çeşitliliği sağlanmış ve üretimde farklı riskler ortaya çıkmıştır. $\mathrm{Bu}$ riskler ile mücadele etmek amaciyla üreticiler risk yönetim stratejileri uygulamakta olup sigorta yapan üreticilerin daha fazla girişimci oldukları görülmektedir. Nitekim modelde sigorta yapan 
üreticilerin girişimcilik düzeylerinin $\operatorname{arttığı~tahmin~}$ edilmektedir (Ağızan, 2018). Ayrıca küçük ölçekli işletmelerde sigorta yaptırma oranı \%35.60 iken, büyük ölçekli işletmelerde bu oran \%78.60 seviyesinde olduğu belirlenmiştir. $\mathrm{Bu}$ durum girişimcilik katsayısının büyük ölçekli işletmelerde daha yüksek olduğunun da bir göstergesi olarak ifade edilmektedir.

Tarım sektöründe girişimciliği etkileyen en temel faktörlerden birisi de ekonomik göstergelerdir. Nitekim ekonomik göstergeler işletmelerin en net başarı kriterlerini ortaya koymakta olup, işletmelerin girişimci olmaları üzerindeki etkileri bu yönde açıklanmıştır. Modelde yer alan dekara GSÜD işletme başarı kriterleri arasında yer alıp, GSÜD artıkça girişimciliğin arttığ belirlenmiştir. Nitekim işletme ölçeklerine göre GSÜD hesaplanmış ve işletme ölçeğinin büyümesine paralel olarak GSÜD'nin dekara düşen değerinde artış görülmüştür. Modelde yer alan bir diğer ekonomik gösterge olan net kâr, tarım işletmelerinde üretimden sorumlu olan ve üretimde organizasyonu sağlayan girişimcinin karıdır (Oğuz ve Bayramoğlu, 2014). İncelenen işletmelerde en net işletme başarı kriteri olan kullanılan net kar, gayrisafi hâsıladan üretim masraflarının çıkartılmasıyla elde edilmektedir. Üretim masrafları ise işletme masrafları ile aktif sermayenin faizinin toplamına eşittir. Aktif sermayenin faizi veya rantı ise, girişimcilerin üretime yatırdığı sermayenin getirisi olarak üretime dahil edilmektedir. Özellikle işletme masraflarına ilaveten bu faizin de eklenmesiyle üreticinin üretim faaliyetleri boyunca katlanması gereken bütün masraflar eklenmiş olmaktadır. Aktif sermayenin hesaplanmasında \%5 faiz oranı dikkate alınmıştır (Bayramoğlu ve ark., 2014). Dekara GSÜD ve net kâr işletme ölçeğinin büyümesine paralel artmaktadır. Yapılan modelleme sonucunda ise net kârın dekara düşen değeri yükseldikçe girişimciliğin arttığ belirlenmiştir. Nitekim yapılan çalışmada da işletme ölçeklerine göre net kâr küçük ölçekli işletmelerde negatif çıkmıştır. Orta ve büyük ölçekli işletmelerde bu değer pozitifi olarak görülmüş olup, işletme ölçeği büyüdükçe net kâr arttığı bulunmuştur. Küçük işletmelerde net kârın negatif çıkmasına rağmen üretime devam edebilmesinin sebebi olarak ise tarım, bu ölçekte üretim faaliyetinde bulunan üreticiler için daha çok yaşam tarzı olarak kabul edilmesinden kaynaklanmaktadır. Ayrıca üreticiler genellikle sabit masraflar içerisinde önemli bir tutan amortisman masraflarını ve aile işgücü ücret karşılığını dikkate almadıkları için, eğer elde edilen üretim değeri değişen masrafların karşılanması durumunda üretime devam ettikleri görülmektedir. Nitekim ekonomi teorisinde de bu nokta üretim eşiği olmakta ve üreticiler ürünlerini toplam değişen masrafları karşlayana kadar üretmektedirler. Bu noktadan daha düşük bir değer seviyesi üretime devam etmeyeceklerini göstermektedir (Erkuş ve ark., 1995; İnan, 1998; Oğuz ve Bayramoğlu, 2018).

Araştırma sonucunda elde edilen sonuçlar ile tarım işletmelerinde üretim faktörlerinin yanı sıra sosyal ve ekonomik faktörlerin girişimciliği etkiledikleri belirlenmiştir. Nitekim bu durum daha önceki yapılan çalışmalarda da uyum göstermektedir. McElwee ve Robson (2005) yılında yaptıkları çalışmada tarımsal girişimciliği politik, sosyal, ekonomik, teknik ve kişisel özelliklerin etkilediğini belirlemiştir. Ayrıca tarımsal girişimciliği ölçek ekonomileri, tarım işletmelerinin sermaye yapılarının, tecrübelerin, yönetim becerilerinin, girişimci ruhun eksik olması, mevcut yasa ve düzenlemelerin, dağıtım kanallarının ve pazara yakınlık gibi faktörlerin girişimciliği etkilemektedir (Gasson, 1998; Falconer, 2000; Kupiainen ve ark., 2000; Sikorska, 2001; Eskelinen ve ark., 2002; Rantamaki-Lahtinen ve Vihinen, 2004; McElwee ve Robson, 2005; Poot ve ark., 2006).

\section{SONUC}

Girişimcilik, ekonominin gelişimi için gerekli olmakla birlikte özellikle gelişmiş ülkeler, ekonomik büyümelerini girişimcilik düzeylerinin yükselmesine bağlamaktadır. $\mathrm{Bu}$ kapsamda girişimciliğin gelişmekte olan ülkelerde de yaygınlaşması gerekliliği ortaya çıkmaktadır. Tarım gibi sermaye devir hızının düşük olduğu ve buna bağlı olarak sermaye birikiminin yetersiz olduğu sektörlerde girişimcilik faaliyetlerinin artırılması son derece önemlidir. $\mathrm{Bu}$ nedenle son yıllarda gida güvenliğinin artması ve iklimsel faktörlerde farklılıklar ortaya çıkmasına bağlı olarak girişimcilik faaliyetlerinin önemi artmıştır. Nitekim girişimcilik ile üretim çeşitliliği ve dolayısıyla gelir çeşitliliği sağlanacak ve tarım işletmelerinde verimlilik ile etkinlik odaklı üretim gerçekleşmiş olacaktır. Tarım işletmelerinde girişimcilik faaliyetlerinin yaygınlaştırılmasında ise birçok faktör etkili olmaktadır. Bu kapsamda tarım işletmelerinde girişimciliği etkileyen faktörler çoklu regresyon analizi ile belirlenmiştir. Yapılan analiz sonucuna göre; tarım işletmecilerinin eğitim düzeylerinin yükselmesiyle ve genç yaşta olan üreticilerin tarım sektöründe faaliyet göstermesiyle girişimcilik düzeyi arasında doğru bir orantı vardır. Ayrıca modelde yer alan sigorta yaptıran, işletmelerin dekara GSÜD ve net kârları, EİB ve arazi varlığ ile girişimcilik arasında pozitif yönlü bir ilişki belirlenmiştir. Elde edilen bu sonuçlara göre var olan girişimciliğin ortaya çıkarılması için öneriler sunulmuştur.

Gelişmiş ülkelerde katma değeri yüksek ürünlerin üretilmesi cari açığın kapatılmasında etkili olacağı düşünülmektedir. Özellikle organik ve doğal ürün üretiminin teşvik edilmesi, gıda tüketiminde önemli bir yer tutan ürünlerin üretilmesi, son ylllarda uygulanan yabancı ülkelerde tarım topraklarının işlenmesi gibi uygulamaların artırılması Türkiye'nin net ithalatçı konumunu pozitif etkileyecektir. 
Tarımsal üretim gerçekleştiren girişimcilerin daha yaygınlaşması için ve bu işletmelerin sürdürülebilirlikleri açısından merkezi bir tarım borsasının ve alt ürünlerinin gelişmesiyle kullanılır olması gerekmektedir. Özellikle lisanslı depoculuk bu anlamda özendirici bir faaliyet olabilir. Bilindiği üzere lisanslı depoculuk, depolamaya uygun olan işlenmiş veya yarı işlenmiş ürünlerin kalitelerinin standart hale getirilmesi ve sağlıklı koşullar altında bu ürünlerin mülkiyetini temsil eden ürün senetleri yardımıyla ticaretin yapılmasını öngören bir sistemdir. $\mathrm{Bu}$ sistemle dünya piyasalarında kabul gören emtia ürünlerinin (pamuk, mısır, şeker) üretimi teşvik edilmiş olacaktır.

Tarımsal üretimde bulunan girişimcilerin en önemli problemlerinden birisi etkin finansman kaynaklarına erişmektir. Tarımsal faaliyette bulunan bu girişimcilerin özellikle KOBİ kavramı içerisinde değerlendirilmemesi ve KOSGEB tarafından desteklenmemesi yaşanan en güncel sorun olarak bilinmektedir. Bu durum haksız rekabete ve tarımın kurumsal kimlik kazanmasına engel teşkil etmektedir. $\mathrm{Bu}$ anlamda Küçük orta ölçekli tarım işletmeleri (KOTI) programının hayata geçirilmesi önem arz etmektedir.

Tarımsal girişimcilerin özellikle sahip oldukları sermaye yapıları göz önünde bulundurulduğunda modern teknolojiden yararlanabilmesi için finansal kiralama, ortak makine kullanımı gibi özendirici faaliyet uygulanmalı ve desteklenmelidir. Makinede olduğu gibi hurda teşviki girişimcilerin mevcut makine parklarını yenilemesine yardımcı olmaktadır.

Tarımsal girişimciler için bir diğer önemli sorun ise; projelendirme maliyetleridir. Özellikle yeni yatırıma girişecek girişimcilerin yatırım öncesi uygulamayı planladıkları projenin çizilmesi, tesisatların hazırlanması gibi etmenler kaynak israfina neden olmaktadır. Türkiye'de inşaat projelerinin çizilmesinde etkin bir ol oynayan TOKİ bu bağlamda bir çözüm olabilir.

Tarım işletmecilerinin yaşları araştırma sonuçlarına göre ortalama 43 olarak belirlenmiştir. Buna göre özellikle tarım işletmecilerinin eğitim düzeylerinin artırılması ancak yapılacak olan girişimcilik eğitimleri ile mümkün olacaktır. $\mathrm{Bu}$ anlamda girişimcilik potansiyellerinin ortaya çıkarılması ve yönlendirilmesi adına üreticilere yönelik girişimcilik eğitim programlarının hazırlanması önemlidir.

Araştırma sonuçlarına göre sigortalılık ile girişimcilik arasında doğru orantılı bir ilişki belirlenmiş olup, sigorta yaptıran üretici sayısını artırmak için farklı yönlendirmeler uygulanmalıdır. Özellikle eksperlerin iyi bir eğitim almaları ve objektif değerlendirme kriterlerine sahip olmaları ile sigorta desteklerinin devlet tarafından karşlanan oranlarında yükseltmelerin yapılması sigortalılığı artıracaktır.
Ayrıca tarımsal üreticiler arasında tarım sigortasını yanı sira gelir sigortasının da yapılması bu durumu daha da güçlendirecektir.

$\mathrm{Bu}$ önerilerin işletme yöneticilerinde var olan girişimcilik özelliklerini belirginleştireceği düşünülmektedir. Nitekim girişimcilik doğuştan değil, sonradan kazanılan bir olgu olup, bu olgu ancak doğru yönlendirmeler sayesinde ortaya çıkacak ve ülke kalkınmasına yardımcı olacaktır.

\section{TEŞEKKÜR}

Bu çalışma Selçuk Üniversitesi Bilimsel Araştırmalar Koordinatörlüğü tarafından desteklenen 17201049 no'lu proje" ile desteklenmiş̧ir

\section{KAYNAKLAR}

Ağızan K 2018. Tarımsal İşletmelerde Girişimciliği Etkileyen Faktörlerin Analizi. Selçuk Üniversitesi Fen Bilimleri Enstitüsü Tarım Ekonomisi Ana Bilim Dalı, Yüksek Lisans Tezi, 278 s.

Arıkan C 2016. Kadın Girişimcilikte Başarı ve Başarıyı Etkileyen Faktörler: Bursa Örneği. Yönetim ve Ekonomi Araştırmaları Dergisi, 14(3): 138-156.

Bal H, İşcan E, Katar B 2016. Ekonomik Büyümede Girişimcilik Eğitiminin Önemi. International Conference On Eurasian Economies, 29-31 August, Kaposvár.

Balaban Ö, Özdemir Y 2008. Girişimcilik Eğitiminin Girişimcilik Eğilimi Üzerindeki Etkisi: Sakarya Üniversitesi İİBF Örneği. Girişimcilik ve Kalkınma Dergisi, 3(2): 133-147.

Bayramoğlu Z, Karakayacı Z, Candemir S 2013. Küçük ve Orta Ölçekli Tarım İşletmelerinde Girişimcilik. 7th International Academic Conference, Prague, Czech Republic, 66-72.

Bayramoğlu Z, Karakayacı Z, Çelik Y, Gündüz O 2014. Tarımsal İşletme Tipolojilerine Göre Risk Faktörlerinin Algılanması Ve Risk Yönetim Stratejilerinin Belirlenmesi. TÜBİTAK Projesi, 113K445, $184 \mathrm{~s}$.

Bayramoğlu Z, Bozdemir M 2018. Tarımda Teknoloji Kullanımının İşgücü Verimliliğine ve İstihdama Etkisi. 2. Uluslararası Ekonomi Araştırmalar ve Finansal Piyasalar Kongresi, 12-14 Nisan, Nevşehir.

Berglann H, Moen ER, Røed K, Skogstrøm JF 2011. Entrepreneurship: Origins and Returns. Labour Economics, 18 (2): 180-193.

Bozdemir M 2017. Dane Misır Üretiminde Kaynak Kullanım Etkinliğinin Belirlenmesi: Konya İli Örneği. Selçuk Üniversitesi Fen Bilimleri Enstitüsü, Tarım Ekonomisi Ana Bilim Dalı, Yüksek Lisans Tezi, 348 s.

Bozkurt ÖÇ, Alparslan AM 2013. Girişimcilerde Bulunması Gereken Özellikler ile Girişimcilik Eğitimi: Girişimci ve Öğrenci Görüşleri. 
Girişimcilik ve Kalkınma Dergisi, 8(1): 7-28.

Chandrashekar S, Bahal R 2014. Factors Influencing the Entrepreneurial Behaviour of Agricultural Graduates. SAARC Journal of Agriculture, 10 (2): 31-39.

Duran C, Büber H, Gümüştekin GE 2013. Girişimcilik Hislerine Eğitimin Katkısı: Kütahya Meslek Yüksek Okulu Makine Programı Örneği. Girişimcilik ve Kalkınma Dergisi, 8(2): 33-56.

Erkuş A, Bülbül M, Kıral T, Açıl A, Demirci, R 1995. Tarım Ekonomisi. Ankara Üniversitesi Ziraat Fakültesi Eğitim, Araştırma ve Geliştirme Vakfı Yayınları No:5, $298 \mathrm{~s}$.

Esiobu N, Nwosu C, Onubuogu, G 2014. Economics of Pineapple Marketing in Owerri Municipal Council Area Imo State Nigeria. International Journal of Applied Research and Technology, 3(5): 3-12.

Esiobu N, Ibe G 2015. Analysis of Entrepreneurship Development in Agriculture Among Arable Crop Farmers in Imo State Nigeria. International Journal of African and Asian Studies, 7: 92-99.

Eskelinen H, Hannibalsson I, Malmberg A, Maskell P, Vatne E 2002. Competitiveness, Localised Learning and Regional Development: Specialization and Prosperity in Small Open Economies. Routledge Frontiers of Political Economy, Routledge, 1 edition, $272 \mathrm{~s}$.

Falconer K 2000. Farm-Level Constraints on AgriEnvironmental Scheme Participation: A Transactional Perspective. Journal of Rural Studies, 16 (3): 379-394.

Gasson R 1998. Educational Qualifications of UK Farmers: A Review. Journal of Rural Studies, 14 (4): 487-498.

Ghiasy FG, Hosseini SJF, Malekmohammadi I, Hosseini, SM 2009a,b. Factors Influencing the Entrepreneurship in Iran's Agricultural Cooperatives. Australian Journal of Basic and Applied Sciences, 3(2): 1170-1176.

İnan İH 1998. Tarım Ekonomisi ve İşletmeciliği. Tekirdağ, Yayın No:1, $413 \mathrm{~s}$.

İpçioğlu İ, Taşer A 2009. İşletme Bölümlerinde Verilen Eğitimin Girişimci Adayı Öğrenciler Üzerindeki Etkileri. Süleyman Demirel Üniversitesi Sosyal Bilimler Enstitüsü Dergisi, 10(2): 13-25.

Kalaycı Ş 2010. SPSS Uygulamalı Çok Değişkenli İstatistik Teknikleri. Asil Yayın Dağıtım, Ankara, $426 \mathrm{~s}$.

Kerse G, Babadağ M, Kerse Y 2017. Girişimcilik Eğitiminin Girişimcilik Niyetine Etkisi: Girişimsel Öz-Yetkinliğin Aracı Rolü. Süleyman Demirel Üniversitesi Sosyal Bilimler Enstitüsü Dergisi, 29 (4): 633-656.

Kumar T 2016. Factors Affecting Development of Agrientrepreneurship in Bhagalpur District of Bihar. Bihar Agricultural College, Bhagalpur Bihar Agricultural University, Sabour Bhagalpur, Agricultural Economics Master Thesis, $151 \mathrm{~s}$.
Kupiainen T, Helenius J, Kaihola O, Hyvönen S 2000. Maaseudun Pienyrityksen Menestyminen. Maatalouden Taloudellinen Tutkimuslaitos Agricultural Economics Research Institute, Research Reports: 239, Finland.

Lashgarara F, Azizian E, Mehdizadeh H 2011. Factors Influencing the Effectiveness of Entrepreneurship Courses on Agricultural Graduates at the Llam Province in lran. African Journal of Agricultural Research, 6 (14): 3428-3431.

McClelland DC 1967. Achieving society (Vol. 92051). Simon and Schuster.

McElwee G, Robson A 2005. Diversifying the Farm: Opportunities and Barriers. Journal of Rural Research and Policy (4): 84-96.

Müftüoğlu MT, Haliloğlu N 2009. Nasıl girişimci olunur?. Turhan Kitabevi, 307 s.

Oğuz C, Bayramoğlu Z, Ağızan S, Ağızan, K 2017. Tarım İşletmelerinde Tarımsal Mekanizasyon Kullanım Düzeyi, Konya İli Örneği. Selçuk Tarım ve Gida Bilimleri Dergisi, 31 (1): 63-72.

Oğuz C, Bayramoğlu Z 2018. Tarım Ekonomisi Kitabı. Atlas Kitapevi, 3.Baskı, 1-222.

Olowa OW, Olowa OA 2015. Factors Affecting Entrepreneurship Development in Agribusiness Enterprises in Lagos State, Nigeria. Global Journal of Management and Business Research, 15(7): 2432.

Onay M, Çavuşoğlu S 2010. İşletmelerde Girişimcilik Özelliğini Etkileyen Faktörler: İ̧ Girişimcilik. Yönetim ve Ekonomi Dergisi, 1(17): 47-67.

Öztürk MD 2016. Türkiye'de Kadın Girişimcilik: Kadınları Girişimciliğe Yönelten Faktörler, Karşılaştıkları Sorunlar ve Çözüm Önerileri. İstanbul Ticaret Üniversitesi Dış Ticaret Enstitüsü Uluslararası Ticaret Anabilim Dalı, Yüksek Lisans Tezi, $125 \mathrm{~s}$.

Poot E, Balk-Theuws A, de Buck J, Buurma J, Van der Lans C, de Wolf P 2006. Voorlopers en Voortrekkers, Ondernemerschap in Netwerkencase Plant, Netherlands: Wageningen University and Research Centre.

Rantamaki-Lahtinen L, Vihinen H 2004. The Role of Equine Industries in Finnish Rural DevelopmentRural Entrepreneurship and Policy Perspectives. Nordic Association of Agricultural Scientists: Horse Management-Premises and Landscape, Seminar No:367, 18-20 October, Finland.

Shane S, Venkataraman S 2000. The promise of entrepreneurship as a field of research. Academy of management review, 25(1): 217-226.

Sikorska A 2001. Przedsiębiorczość na wsi w świetle ankiety IERiGŻ 2000, Wyd. IERiGŻ, Warszawa. Instytut Ekonomiki Rolnictwa i Gospodarki Żywnościowej, 472: 1-25.

Singh MP 2014. Entrepreneur and Economic Development: A Study of Role of Various Forms of Entrepreneurs in Economic Development. Global 
Journal of Multidisciplinary Studies, 3(5): 212-237.

Soleimanpour MR, Hosseini SJF, Mirdamadi SM,

Sarafrazi A 2011. Challenges in Commercialization of Nanotechnology in Agriculture Sector of Iran. Annals of Biological Research, 2 (4): 68-75.

TOB 2017. Tarımsal Makro Ekonomik Göstergeler. http://www.tarim.gov.tr/Konular/Makro-Ekonomik -Gostergeler. (Erişim tarihi: 04.09.2017).

Uygun M, Güner E 2016. Girişimcilik Eğiliminin Gelişiminde Girişimcilik Eğitiminin Rolü. Manas Sosyal Araştırmalar Dergisi, 5 (5): 43-44.

Uysal ÖK 2015. Manisa İli Yunt Dağı Köylerinde Çiftçilerin Tarımsal Üretime Yaklaşımlarını Etkileyen Faktörlerin Analizi. Sosyal ve Beşeri Bilimler Araştırmaları Dergisi, 35: 76-99.

Vakili K, Eyvazlou M, Jamshidi A 2013. Investigating Factors Affecting Entrepreneurship in Agricultural Corporations of Shirvan and Chardavol Towns.
International Journal of Academic Research in Business and Social Sciences, 3(8): 67-78.

Van Altvorst A, Andeweg K, Eweg R, Van Latesteijn H, Mager S, Spaans L 2011. Sustainable Agricultural Entrepreneurship. The Netherlands: TransForum, First Edition: 1-180.

World Bank 2012. World Development Report 2013: Jobs. World Development Report. https://openknowledge.worldbank.org/handle/1098 6/11843.pdf. (Erişim Tarihi: 15.09.2018).

Yalçıntaş M 2010. Çağımızda Girişimcilik. Girişimcilik ve Kalkınma Dergisi, 5(1): 95-98

Yamane $\mathrm{T}$ 1967. Elementary Sampling Theory. Prentice Hall, 1st Edition, 405 s.

Zachary RK, Mishra CS 2010, Entrepreneurship research today and beyond: hidden in plain sight!, Journal of Small Business Management, 48 (4): 471-474. 